\title{
Antimicrobial activity against Macrophomina phaseolina and the control of charcoal rot in soybeans using the homoeopathic drugs Sepia and Arsenicum album
}

\author{
Atividade antimicrobiana contra Macrophomina phaseolina \\ e controle de podridão cinzenta da haste em soja pelos \\ medicamentos homeopáticos Sepia e Arsenicum album
}

Eloísa Lorenzetti ${ }^{*}$, José Renato Stangarlin' ${ }^{1}$ Odair José Kuhn ${ }^{1}$

| | | | | | | | | | | | | | | | | | | | | | | | | | | | | | | | | | | | | | | | | | | | | | | | | | | | | | | | | | | | | | | | | | | | | | | | | | | | | | | | | | | | | | | | | | | | | | | | | | | | | | | | | | | | | | | | | | | | | | | | | | | | | | | | | | | | | | | | | | | | | | | | | | | | | | | | | | | | | | | | | | | | | | | | | | | | | | | | | | | | | | | | | | | | | | | | | | | | | | | | | |

\begin{abstract}
The aim of this study was to evaluate the control of charcoal rot in soybeans using Sepia and Arsenicum album homeopathic solutions in dynamizations of $6,12,24,36$ and $48 \mathrm{CH}$ (hahnemanian centesimal scale), in addition to verify the antimicrobial activity of these treatments against Macrophomina phaseolina. Additional treatments were also used, including distilled water and a hydroalcoholic solution of $30 \%$ ethanol. In vitro tests were performed to analyze the number of microsclerotia and the mycelial growth of the fungus. In vivo assays were used to evaluate the progress of the disease and the size of the lesions. For the area under the mycelial growth curve (AUMGC), A. album had no effect, however, Sepia reduced up to $32 \%$ of the fungal growth. For micro-sclerotia there was no statistical difference. For the area under the disease progress curve (AUDPC), both Sepia and A. album in $24 \mathrm{CH}$ dynamization reduced fungal growth up to $50 \%$ and $70 \%$ in the first and second assays, respectively, compared to control treatments. These results indicate the potential of these homeopathic drugs for controlling soybean charcoal rot.
\end{abstract}

KEYWORDS: alternative control; Glycine max; homeopathy.
RESUMO: O objetivo deste estudo foi avaliar o controle da podridão cinzenta da haste em soja, pulverizando soluçóes homeopáticas de Sepia e Arsenicum album, nas dinamizaçóes 6, 12, 24, 36 e 48CH (centesimal hahnemaniana), bem como verificar a atividade antimicrobiana desses tratamentos contra Macrophomina phaseolina. Como tratamentos adicionais utilizou-se água destilada e soluçáo hidroalcoólica a $30 \%$ de etanol. Foram realizados ensaios in vitro a fim de analisar o número de microescleródios e o crescimento micelial do fungo, e ensaios in vivo para acompanhar o progresso da doença e o tamanho da lesão. Para área abaixo da curva de crescimento micelial (AACCM), A. album não apresentou efeito, no entanto, Sepia reduziu em até $32 \%$ o crescimento. Para microescleródios não houve diferença estatística. Para área abaixo da curva de progresso da doença (AACPD), tanto Sepia quanto $A$. album na dinamização $24 \mathrm{CH}$ apresentaram reduçáo de até $50 \%$ no primeiro ensaio e de até $70 \%$ no segundo ensaio quando comparados com a solução hidroalcoólica. Estes resultados indicam o potencial desses medicamentos homeopáticos no controle de podridão cinzenta da haste em soja.

PALAVRAS-CHAVE: controle alternativo; Glycine max; homeopatia. 


\section{INTRODUCTION}

Brazil is the second largest soybean producer in the world, after the United States, with a production of 98,981.6 thousand tons (CONAB, 2016).

Over the years, with the increase of cultivated soybean area, there has been an emergence of diseases that harm productivity. One of the most important soybean diseases is charcoal rot, which is caused by the fungus Macrophomina phaseolina (Tassi) Goid (1947), which infects the roots and the lower part of the stem of the plant, causing first, discoloration, and then a dark brown or black color (ALMEIDA et al., 2014).

When the climate is favorable, in other words, in periods of drought and very high temperature, the disease can attack young and adult plants, and the infection usually occurs in the middle of the plant cycle (ALMEIDA et al., 2014). Pathogens that cause root rot are considered the most difficult to control and among these, REIS (2004) cites M. phaseolina.

Due to the dangerousness of the disease, it is necessary to control it. The control is based on: the practice of no tillage and the use of plants for covering the soil, in order to avoid water stress; chemical and physical soil management; strictness in the planting season; use of recommended varieties for a particular region; and the development of environments that do not let the fungus thrive (EMBRAPA, 2004), as well as alternative methods of control, such as homeopathic treatment.

Homeopathic drugs are any pharmaceutical material applied according to the principle of similarity. They aim to be preventive and therapeutic and are obtained by the method of dilutions followed by successive dynamization and/or crushing. Dynamization consists of the vigorous and rhythmic agitation of drugs dissolved in suitable inert material and dynamization is the result of the dilution process followed by successive succussion and/or trituration of the drug (ANVISA, 2011).

There are no specific medical materials or repertoires for plants, only for humans (CARNEIRO et al., 2011). Therefore, the analogy between the human symptoms described in the Human Medical Matter and the symptoms presented by the plants are used. Sepia and Arsenicum album were chosen, because when performing a repertorization through the analogy with human symptoms, they obtained the highest score for the symptoms presented by plants affected by charcoal rot.

Several studies have already been carried out regarding the use of homeopathy on a wide range of crops, such as basil, lettuce, strawberry, beets, carrots, tomatoes, corn, beans and others. They show that, by using homeopathy, it is possible to raise crop productivity, adapt vegetative material to various production systems and still induce plant resistance to the attack of both pests and diseases caused by plant pathogens
(SAXENA et al., 1987). Studies using Sepia and Arsenicum album have already been performed, however, they were used in other pathosystems. As a result, this study is a way of confirming the potential of these homeopathic drugs indicated by repertorization.

According to CARNEIRO et al. (2011), alternative methods for agriculture are methods developed in a sophisticated and complex system of agronomic techniques, which seek not only to enable immediate and inconsequent economic benefits, but also long-term economic benefits, permitting the maintenance of a stable and self-sustaining agro-ecosystem.

The present study aimed to develop an alternative method using the homeopathic drugs Sepia and Arsenicum album against M. phaseolina, and to verify the in vitro antimicrobial activity and the control of charcoal rot in soybean plants.

\section{MATERIAL AND METHODS}

Two assays were performed. One, in vitro, was carried out in a laboratory and the other, in vivo, was conducted in a greenhouse. Both in vivo and in vitro assays used the fungus M. phaseolina, which was isolated from soybean plants with symptoms of the disease.

For the in vivo assay, the fungus $M$. phaseolina was cultivated in Petri dishes with a PDA medium (potato, dextrose and agar) and after the fungus presented micro-sclerotia, disks from the culture medium containing $M$. phaseolina were used for inoculation of the plants in the pots. The conventional soybean cultivar NK 412113 (conventional V-MAX) was used. The fungus was maintained in a PDA medium for later use.

For the choice of treatments, the most peculiar symptoms of charcoal rot were observed in plants affected by the disease. These symptoms were then compared. An analogy was made with the human symptoms, and then it was possible to verify the information of the indicated drugs (Sepia and Arsenicum album), by consulting the medical matter.

The repertorization showed that Sepia and Arsenicum album had the highest score. Studying the medical material of both, they were found to be the most suitable homeopathic drugs for charcoal rot.

These drugs were obtained in a homeopathic pharmacy in the $6 \mathrm{CH}$ dynamization and manipulated in 12, 24, 36 and $48 \mathrm{CH}$ (centesimal hahnemanian), according to the Brazilian Homoeopathic Pharmacopoeia (2011), diluting 1:100 and shaking 100 times. Additional treatments we also used, including distilled water and 30\% ethanol hydro alcoholic solution. Water and ethanol were used since they are the diluents in the preparations of the homeopathic medicines.

To determine antifungal activity, the homeopathic drugs Sepia and Arsenicum album were used in the appropriate dynamizations, and were incorporated into the culture 
medium (PDA), still in liquid form and at a warm temperature $\left(60^{\circ} \mathrm{C}\right)$ in Erlenmeyer flasks. We used $0.005 \%$ or 5 $\mu \mathrm{L}$ of the treatment for each $100 \mathrm{~mL}$ of the PDA culture medium (BONATO, 2007). After that, the PDA medium was poured and the solidification was complete. A disk, taken from the colony of the fungus, was added to the center of each Petri dish in order to grow. The dishes were incubated at $25^{\circ} \mathrm{C}$ in the dark.

Daily measurements started 24 hours after the experiment was set up and only ended when the fungal colonies reached the edges of the Petri dish. These measurements were performed according to the methodology described by STANGARLIN et al. (1999) using the method of diametrically opposed measurements to evaluate the diameter of the colony.

At the end of the daily measurements to determine the area under the mycelial growth curve (AUMGC), $0.1 \mathrm{~cm}^{2}$ of the fungus was removed, standardizing the removal site (between the center and the border of the Petri dish), and the number of micro-sclerotia in the stereomicroscope was counted.

In vivo assays were performed in two tests, and in both of them $1 \mathrm{~L}$ pots containing the mixture of soil, sand and organic matter in a ratio of 2:1:1 were sterilized in an autoclave at $120^{\circ} \mathrm{C}$ for $1 \mathrm{~h}$.

The inoculum of $M$. phaseolina was produced in the PDA medium, and for each pot, three discs that were removed from the BDA medium, which was colonized with a micro-sclerotia of the fungus, were added.

Three soybean plants per pot were maintained and each inoculum disc was placed next to a soybean plant so that the mycelium of the fungus came into contact with the plant root. The inoculation occurred when the plants emitted the first trifoliate leaf, and after inoculation, the surface of the pots was covered with hay.

Treatments were administered by spraying three days before inoculation, on the day of inoculation, and 3, 10 and 17 days after inoculation. The treatments were applied to the soil in the proportion of $0.1 \%(1 \mu \mathrm{L}$ per pot). Measurements of lesion growth were made on the plant stem every two days using a graduated ruler. With the obtained data, a calculation was made to find the area under the disease progress curve (AUDPC).

For the in vitro assay, the experimental design was completely randomized, whereas in the in vivo assay, the design was organized into randomized blocks, and both had five replicates. Data were submitted to regression analysis. The factorial was $2 \times 5+2$, with 2 being the number of drugs (Sepia and Arsenicum album), 5 the number of dynamizations that were used $(6,12,24,36$ and $48 \mathrm{CH})$, and 2 corresponded to the additional treatments (water and ethanol 30\%).

If there was no significant difference for the factorial or for the additional treatment, the data were shown in a table, otherwise graphs were made.

\section{RESULTS AND DISCUSSION}

Arsenicum album had no effect on the area under the mycelial growth curve, however, Sepia inhibited the fungus, which was represented by a quadratic equation, and had a reduction of up to $32 \%$ (Fig. 1).

For micro-sclerotia there was no statistical difference between treatments (Table 1).

For the control of charcoal rot in soybean plants, it was observed that for both drugs, the behavior was similar. The behavior was represented by quadratic equations. For the first assay, both Sepia and Arsenicum album in the dynamization $24 \mathrm{CH}$ showed an AUDPC reduction of 50\% when compared to the hydro alcoholic solution (Fig. 2). The same thing was observed in the second assay, where both Sepia and Arsenicum album

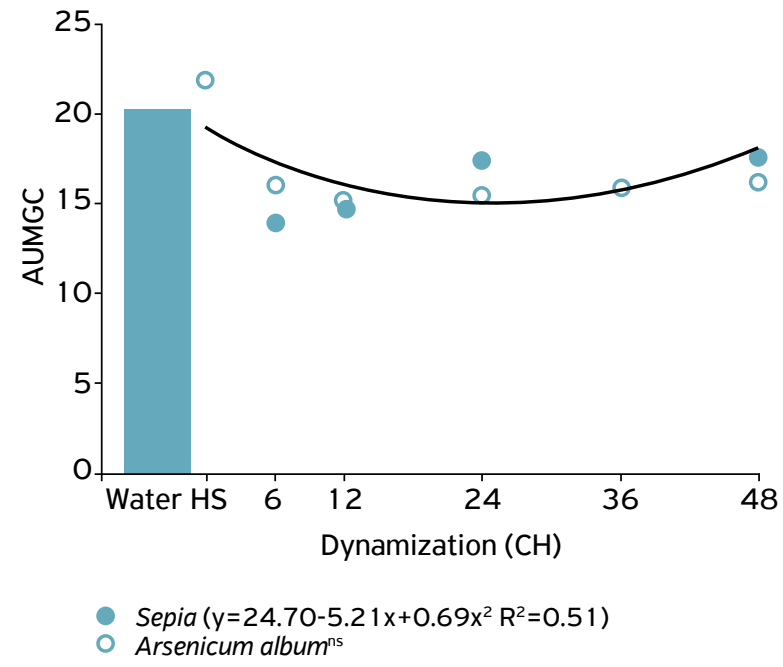

ns: No significance among dynamizations of the same drug or between drugs; HS: hydro alcoholic solution (30\% ethanol).

Figure 1. Area under the mycelial growth curve (AUMGC) of Macrophomina phaseolina in a PDA medium with dynamizations of the homeopathic drugs, Sepia and Arsenicum.

Table 1. Quantity of micro-sclerotia of Macrophomina phaseolina in a PDA medium supplemented with dynamizations of the homeopathic drugs, Sepia and Arsenicum album.

\begin{tabular}{|c|c|c|c|c|}
\hline $\begin{array}{l}\text { Dynamization } \\
\text { (CH) }\end{array}$ & Sepia & Average & $\begin{array}{l}\text { Arsenicum } \\
\text { album }\end{array}$ & Average \\
\hline 6 & $79.16^{\text {ns }}$ & & $73.86^{\text {ns }}$ & \\
\hline 12 & 65.26 & & 100.33 & \\
\hline 24 & 121.36 & 96.04 & 97.03 & 95.11 \\
\hline 36 & 126.14 & & 68.35 & \\
\hline 48 & 73.74 & & 120.49 & \\
\hline \multicolumn{4}{|c|}{$\begin{array}{l}\text { Average of additional treatment } \\
\text { with } 30 \% \text { ethanol solution }\end{array}$} & 110.62 \\
\hline \multicolumn{4}{|c|}{ Average of additional treatment with water } & 141.28 \\
\hline \multicolumn{4}{|l|}{ Factorial average } & 95.58 \\
\hline C.V. (\%) & $26.34 x$ & & 23.14 & \\
\hline
\end{tabular}

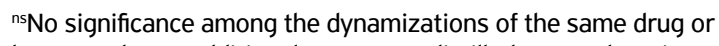
between drugs; additional treatment: distilled water; the micro-sclerotia count data were transformed to root of $x+0.5$. 
presented the greatest reductions of AUDPC in the dynamization $24 \mathrm{CH}$. The AUDPC was reduced up to $70 \%$ when compared to the hydro alcoholic solution (Fig. 3). In a study carried out by KHANNA; CHANDRA (1977), using Arsenicum album $181 \mathrm{CH}$, there was $100 \%$ control of the rot caused by Pestalotia psidii in guava fruits. This shows the efficiency of the drug even though it was used in another pathosystem.

Except for the work of KHANNA; CHANDRA (1977), no results were found in the literature where Arsenicum album was used to control plant diseases. Studies were only found where growth variables were evaluated. Although growth variables were

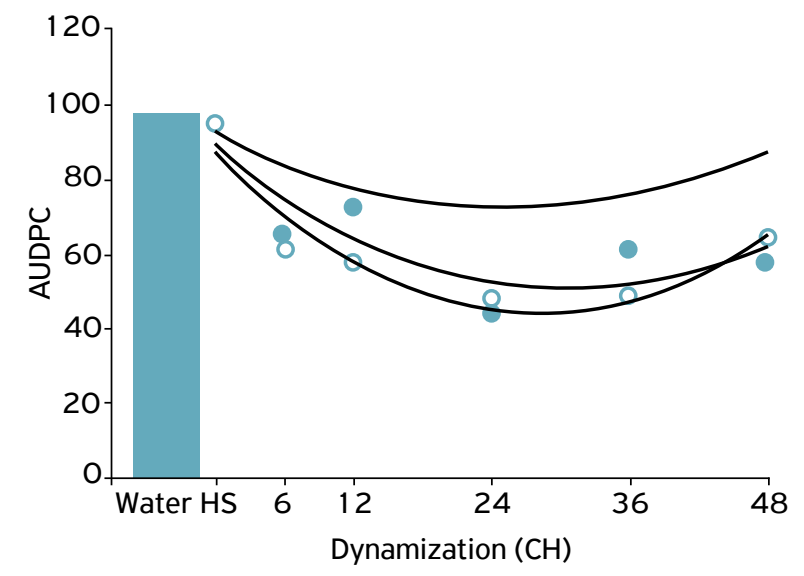

Sepia $\left(y=88.43-3.18 x+0.05 x^{2} R^{2}=0.89\right)$

- Arsenicum album $\left(y=89.67-2.50 x+0.04 x^{2} R^{2}=0.73\right)$

HS: Hydro alcoholic solution (30\% ethanol).

Figure 2. Area under the disease progress curve (AUDPC) of Macrophomina phaseolina from the first experiment carried out in potted soybean plants grown in a greenhouse and treated with dynamizations of the homeopathic drugs, Sepia and Arsenicum album.

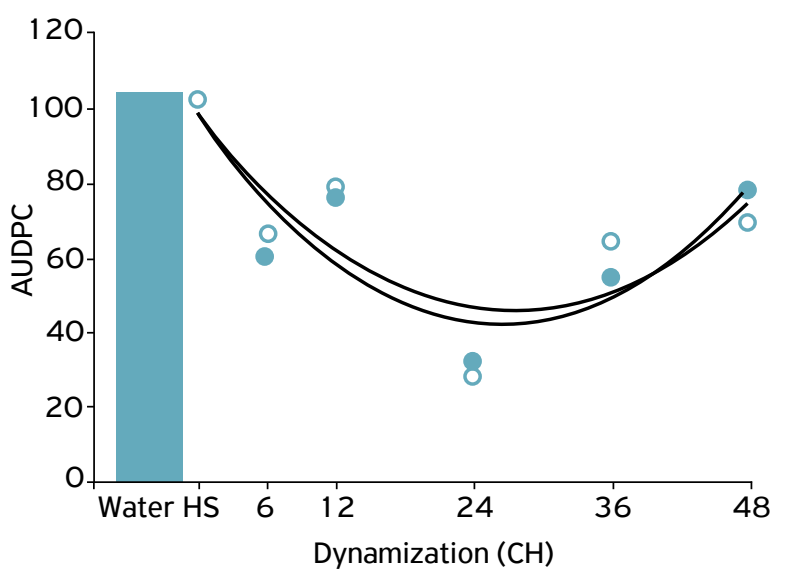

Sepia $\left(y=89.7179-3.5416 x+0.6865 x^{2} R^{2}=0.54\right)$

- Arsenicum album $\left(y=90.12-2.65 x+0.62 x^{2} R^{2}=0.50\right)$

HS: Hydro alcoholic solution (30\% ethanol).

Figure 3. Area under the disease progress curve (AUDPC) of Macrophomina phaseolina from the second experiment carried out in potted soybean plants grown in a greenhouse and treated with dynamizations of the homeopathic drugs Sepia and Arsenicum album. not assessed in this study, through visible observation, it was concluded that some plants, although diseased, were in a better state than before the treatment, when compared to the others.

In the work of MARQUES et al. (2011), which was carried out with sorghum seeds that were treated with the homeopathic drug Arsenicum album at different dilutions and dynamizations, there was an increase in the hypocotyl stretching in the dilutions 12 and $24 \mathrm{x}$ and dynamizations 12,18 and $24 \mathrm{CH}$, whereas the dilutions 18, 24 and 30x and the dynamization $18 \mathrm{CH}$ stimulated early growth in seedlings.

Testing the germination and the development of seeds and seedlings of a white bean (Phaseolus vulgaris L.) under the influence of high dilutions, ZANCO et al. (2013) used Arsenicum album at 2, 6, 10, 14, 20, 30, 200 and 1,000 $\mathrm{CH}$ from two drug stores ( 1 and 2). Store 1 had a manual preparation and store 2 had a mechanical one. A number of bean seeds were dipped into drugs for $12 \mathrm{~h}$, and it was observed that for the drugs from drug store 1, Arsenicum album 30, 20 and $1000 \mathrm{CH}$ had a significant effect on the increment of fresh matter of the aerial part.

These studies mentioned show the ability of Arsenicum album to keep the plant alive for longer, which can cause diseases to develop less quickly. The same findings were observed in this study.

A resistance inducer must activate the defense mechanisms of the organism. This resistance is complex since it is composed of several factors (SOARES; MACHADO, 2007). Plant defense mechanisms, which were developed in the course of the co-evolution between the pathogen and its host, can be activated, preventing disease development (QUERINO et al., 2005). It is possible that the drugs only acted as resistance inducers, making plants more resistant, but did not actually eliminate the pathogen or the plant's disease. This may be one of the reasons why some plants were shown to be more vigorous than others that were equally as diseased, but which were weakened and died before the more resistant ones.

It should be taken into account that the concentration of the inducer or drug may cause this induction effect (CHINNARSRI et al., 2003). Additionally, the obtained results should be taken into consideration according to the varied hosts, nutritional status and the type of pathogen involved (ASSUNÇĀO et al., 2010).

Although there was no record of the use of Sepia in diseased plants, through this study, it was verified that it was also effective, since there was no difference between it and Arsenicum album.

\section{CONCLUSION}

The homeopathic drugs Sepia and Arsenicum album in the dynamizations tested were able to reduce the area under the disease progress curve of charcoal rot in soybeans, although only Sepia showed direct fungitoxic activity against $M$. phaseolina, which was represented by the reduction of mycelial growth. 


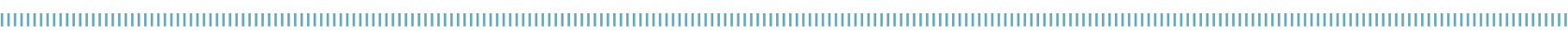
REFERENCES

AGÊNCIA NACIONAL DE VIGILÂNCIA SANITÁRIA (ANVISA). Farmacopéia Homeopática Brasileira. 3. ed. São Paulo: Atheneu, 2011.

ALMEIDA, A.M.R.; SEIXAS, C.D.S.; FARIAS J.R.B.; OLIVEIRA, M.C.N.; FRANCHINI, J.C.; DEBIASE, H.; COSTA, M.C.; GAUDÊNCIA, C.A. Macrophomina phaseolina em soja. Londrina: Embrapa Soja, 2014. 55p. (Documentos, 346).

ASSUNÇÃO, A.; SANTOS, L.C.; ROCHA, M.R.; REIS, A.J.S.; TEIXEIRA, R.A.; LIMA, F.S.O. Efeito de indutores de resistência sobre Meloidogyne incognita em cana-de-açúcar (Saccharum spp.). Nematologia Brasileira, v.34, n.1, p.56-62, 2010.

BONATO, C.M. Homeopatia em modelos vegetais. Cultura Homeopática, n.21. p.24-28, 2007.

CARNEIRO, S.M.T.P.; TEIXEIRA, M.Z.; NECHAR, R.M.C.; LONNI, A.A.; RODRIGUES, M.R; FILIPPSEN, L. Homeopatia: princípios e aplicações na agroecologia. Londrina: IAPAR, 2011.

CHINNASRI, B.; SIPES, B.S.; SCHMITT, D.P. Effects of acibenzolarS-methyl application to Rotylenchulus reniformis and Meloidogyne javanica. Journal of Nematology, v.35, n. 1, p. 1 10-1 14, 2003.

COMPANHIA NACIONAL DE ABASTECIMENTO (CONAB). Acompanhamento da safra brasileira de grãos. Safra 2015/16, n.7. Sétimo Levantamento. CONAB, 2016. v.1.

EMPRESA BRASILEIRA DE PESQUISA AGROPECUÁRIA (EMBRAPA). Tecnologias de Produção de Soja: Região Central do Brasil. Embrapa Soja, 2004. Available from: <http://www.cnpso.embrapa.br/ producaosoja/doenca.htm>. Accessed on: 18 abr. 2016.

KHANNA, K.K.; CHANDRA, S. Control of guava frut rot caused by Pestalotia psidii with homeopathic drugs. Plant Disease Reporter, v.61, n.5, p.362-366, 1977.

MARQUES, R.M.; REIS, B.; CAVAZIN, A.T.; MOREIRA VILAR, F.C.; BUCHOSKI, M.G.; SILVA, H.A.; LOLIS, M.A.; BONATO, C.M.
Germination and vigour of seed of sorghum (Sorghum bicolor L. Moench) treated with Arsenicum album. In: CONGRESSO BRASILEIRO DE FARMÁCIA HOMEOPÁTICA, 8., SIMPÓSIO DO GIRI, 25., 2011 , Foz do Iguaçu. Proceedings of the XXV GIRI Symposium and VIII CBFH, 2011 v. v. 10. p.239-244.

MARQUES, R.M.; REIS, B.; CAVAZIN, A.C.T.; MOREIRA, F.C.; BUCHOSKI, M.; SILVA, H.A.; LOLIS, M.; BONATO, C.M. Germinação e vigor de sementes de sorgo (Sorghum bicolor L. Moench) tratados com Arsenicum album. Universidade Estadual de Maringá, Maringá, 2011.

QUERINO, C.M.B.; LARANJEIRA, D.; COELHO, R.S.B.; MATOS, A.P. Efeito de dois indutores de resistência sobre a severidade do mal-do-Panamá. Fitopatologia Brasileira, Fortaleza, v.30, n.3, p.239-243, 2005.

REIS, E.M. Doenças na cultura da soja. Passo Fundo: Aldeia Norte, 2004. 178p.

SAXENA, A.; PANDEY, M.L.; GUPTA, R.C. Effect of certain homeopathic drugs on incidence of seed-borne fungi and seed germination of Abelmoschus esculentus. Indian Journal of Mycology (2) Plant Pathology, v.17, p.191-192, 1987.

SOARES, A.M.S.; MACHADO, O.L.T. Defesa de plantas: sinalização química e espécies reativas de oxigênio. Revista Trópica-Ciências Agrárias e Biológicas, v.1, n.1, p.9-19, 2007.

STANGARLIN, J.R.; SCHWAN-ESTRADA, K.R.F.; CRUZ, M.E.S.; NOZAKI, M.H. Plantas medicinais e controle alternativo de fitopatógenos. Biotecnologia, Ciência @ Desenvolvimento, Brasília, v.11.p.16-21, 1999.

ZANCO, J.J.; BOFF, P.; MINKIN, V.A. Análise de sinais bioeletrográficos em sementes de feijão-branco tratadas com altas diluições. Palhoça, 2013. Available from: <https://www.vibraimage.it/Bibliography/ Engl/2013/resumo_expandido_2013.pdf > . Accessed on: Sept. $19,2017$. 